\title{
The Bible, theology and the Dutch Reformed Church in South Africa 1920-2020
}

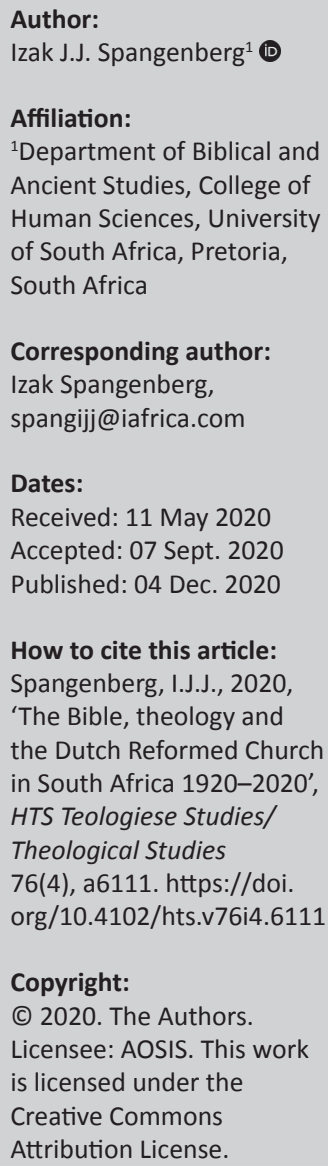

Professor Johannes du Plessis (1868-1935) of the Theological Seminary at Stellenbosch was fascinated by the results of the historical-critical research into the Bible. He acquainted his students and readers of the journal Het Zoeklicht with the results of this way of studying the Bible. However, in 1928, he was accused of heresy for cherishing views not aligned with the reformed confessions of faith. After 2 years and many meetings, he was dismissed as the professor. Being convinced that the Dutch Reformed Synod did not act in good faith, he took his case to the High Court and won. Almost a century later, the General Synod of the Dutch Reformed Church (DRC) once again had to defend a resolution in the High Court. This time it concerned gay marriages and the ordination of people with a homosexual orientation as elders and ministers. The DRC again lost its case and had to retract the resolution of the Special General Synod held in 2016. The underlying issue in both cases is the doctrine of Scripture. Since the Du Plessis case, the DRC has struggled to come to terms with the historical-critical methods of reading and studying the Bible and to formulate a doctrine of Scripture aligned with it. Had it embraced the new way of reading and studying the Bible which emerged in the late 19th and the early decades of the 20th century, its history of support for the apartheid policy and the almost homophobic resolutions concerning gay members might have looked differently.

Contribution: This historical overview on how the Bible has been used in the Dutch Reformed Church (DRC) the past century (1920-2020) highlights the problems which the Bible creates when it is not read as a document from a different time and culture.

Keywords: doctrine of scripture; biblical interpretation; historical-critical methods; Du Plessis case; Afrikaner-Calvinism; Afrikaner nationalism; Cottesloe consultation; Dutch Reformed Church; apartheid policy; ordination of women; gay marriages.

\section{Introduction}

The selection of the dates 1920 and 2020 to demarcate a century in the history of the Dutch Reformed Church (DRC) may seem rather arbitrary because nothing out of the ordinary happened during 1920 and the year 2020 is still in its infancy. ${ }^{1}$ However, there are good reasons for taking 1920 as the beginning of serious reflections on the interpretation and authority of the Bible in the DRC. During that year, professor B.B. Keet, the newly appointed professor in dogmatic theology at the Theological Seminary in Stellenbosch, delivered his inaugural lecture titled 'The authority of Holy Scripture' (Olivier 2009:17). This evidenced that the authority of Scripture was becoming an issue in the DRC. From that year, two different viewpoints concerning the Bible emerged - a more conservative one (associated with the dogmatic tradition of the DRC) and a more critical one (associated with biblical studies). Throughout the century, these two viewpoints influenced ministers' sermons and theological statements as well as the DRC's policies and stances concerning societal issues. This article will focus on events and publications since 1920, which reflect that the two viewpoints remained alive in the DRC throughout the century. It will also argue that the critical viewpoint never succeeded in becoming the dominant one in the DRC. Even though the DRC remained a conservative reformed church at stages during its history, it took bold steps concerning societal and theological issues.

\section{A new paradigm for reading and interpreting the Bible (1920-1935)}

In his brief discussion of the historical-critical method, Edgar Krentz (1975:22) argued a case that the historical method of doing research gained momentum during the century 1820-1920. 1.When I wrote this sentence, the Covid-19 disease was not yet a global threat. What the future may hold remains uncertain. 
This affected geology, biology and even biblical studies and had the effect that a new paradigm in biblical studies emerged towards the end of the 19th and beginning of the 20th century (Noll 1991:45; Sæbø 1995:243-247; Spangenberg 1994:148-156). However, Old and New Testament scholars working within the new paradigm soon had to fend off accusations of cherishing heretical viewpoints concerning the Bible (Spangenberg 2002a:40-42). The heresy case against Professor Johannes du Plessis (1868-1935) of the DRC's Theological Seminary at Stellenbosch is but one example. Like many overseas biblical scholars and theologians (ed. Shriver 1997), he had to defend himself against those who were convinced that a true believer cannot embrace the new paradigm and take the Bible to be a human book 'to be investigated with the standard assumptions that one brings to the discussion of all products of human culture' (Noll 1991:45). A true believer is the one who regards the Bible as the Word of God and interprets it 'by the conventions of common sense' (Noll 1991:45).

Johannes du Plessis was confronted with the results of the paradigm change in biblical studies whilst performing postgraduate studies at the University of Edinburgh in Scotland and visiting the University of Halle in Germany (Erasmus 2009:23-72). Returning to South Africa, he embraced the new paradigm and commenced acquainting readers of Die Kerkbode (the official DRC 'newspaper') with the results of the historical-critical study of the Bible during his term as editor (1910-1912). He resigned in 1912 to travel through Africa and acquaint himself with the continent and the work of Christian missionaries. He traversed the continent no less than three times. He started his journey on the west coast at the mouth of the Niger river and travelled to Mombasa on the east coast. From there, he travelled to the mouth of the Congo river on the west coast and then made an about-turn to travel to the Zambezi river and back to South Africa (Van der Watt 1987:163-164). Thereafter, he published a book with the title Een toer door Afrika (English title Thrice through the dark continent) to inform readers about the interior of Africa and the need for more missionaries to Christianise the indigenous people (Bosch 1986:68). Du Plessis had the ability to remain a devoted Christian eventhough he was convinced that the Bible should be studied in a more critical way than readers were used to. He was, without doubt, a herald of the historical-critical study of the Bible in the DRC, but this made him a suspect and a target for those who cherished conservative theological viewpoints.

To his astonishment, he was called to serve as professor of New Testament at the Theological Seminary in 1915. He and others thought that he might be offered a chair in Missiology. Not all ministers and church members were happy with his appointment in 1916. Some were convinced that his viewpoints might make students astray. However, the students enjoyed his lectures and his weekly prayer meetings made a lasting impression on them (Olivier 2009:17). Professors B.B. Keet (1885-1974) and E.E. van Rooyen (1884-1951) were soon appointed as his colleagues. Keet was appointed as professor of dogmatic theology and Van Rooyen as professor of Old Testament. Both these theologians had studied at the Free University of Amsterdam (Deist 1994:64).

During his tenure as professor, Du Plessis decided to launch a theological journal called Het Zoeklicht ('The Search light') in which he and other critically inclined ministers and theologians discussed theological issues and expressed their viewpoints. Already, in the first issue in 1923, Du Plessis published an article concerning the 'sign of Jonah' (Du Plessis 1923:213-217). The article deviated from the traditional interpretation and introduced readers to the results of a historical-critical reading of Jonah. Van Rooyen immediately reacted and criticised Du Plessis's reading of the story (Van Rooyen 1923:245-249). A conservative group of ministers established their own journal in 1928 labelling it Die Ou Paaie ['The Old Ways']. The aim was to counter Du Plessis's viewpoints, to diminish his influence and to prevent the historical-critical study of the Bible gaining adherents in the DRC (Deist 1994:47, 135).

Du Plessis soon had to defend himself against accusations that his convictions contradicted the reformed confessions (Deist 1986a:36-65). These accusations resulted in him being accused of heresy in 1928. After 2 years and many meetings, he was dismissed as professor at the seminary (Olivier 2009:18). However, he took his case to the High Court and won. The court's verdict was that the Cape Synod did not act according to its own rules when it dismissed Du Plessis. It, therefore, ordered the Synod to rehabilitate him. The DRC accepted the outcome of the court case but informed Du Plessis that, because of the breakdown in trust, it could not reinstate him as professor. His marching orders were properly given at the next synod meeting in 1932 (Deist 1986b:38-39; Hofmeyr 1986:8). The conservative group thus triumphed and the historical-critical study of the Bible received a severe blow (Deist 1994:144-145; Le Roux 1986:33). This had a longlasting effect on theological training at Stellenbosch and on the character of the DRC (Kinghorn 1986a:55-58). The DRC's character changed to that of a reformed church cherishing fundamentalistic viewpoints concerning the Bible (Deist 1986a:60-62, 1994a:135-145; Loader 1979:1-22; Strauss 2015:56).

The new paradigm in biblical studies, which emerged during the late 19th and early 20th century and which Du Plessis tried to acquaint theological students and readers of Het Zoeklicht with, thus did not take root in the DRC's theological training. The majority of professors and ministers in the church adhered to the old paradigm and believed that the Bible 'was invested with the status of a divinely revealed and dictated work' (Kennedy 2006:134). Moreover, it should be read in a realistic way: 'its words meant and described exactly what they said' (Kennedy 2006:134).

During those years, none of the Afrikaans-speaking philosophers or theologians steeped in philosophy were able to draw ministers' attention to the fact that they were 
working with an epistemology called 'common sense realism' (Deist 1988:23-29; Van Heerden 1988:100-139). It was only during later years with the wisdom of hindsight and with knowledge of the philosophy of science and epistemological theories that scholars were able to categorise the viewpoints and arguments of the two main groups in the DRC. Moreover, only when a younger group of biblical scholars entered the scholarly field and acquainted themselves with the research history of the Old and New Testament, did things change for the better in the DRC (Deist 1988:30-31). But for more than 50 years, the old paradigm ruled supreme. The next two sections will deal with historical events, theological statements and DRC reports that evidence this.

\section{The flourishing of conservative convictions (1935-1959)}

During the first six decades of the twentieth century, the DRC consisted of four independent provincial churches with a federal council as an overarching advisory and co-ordinating body. The four churches were (1) the DRC of the Cape Province, (2) the DRC of the Orange Free State, (3) the DRC of Natal and (4) the DRC of Transvaal. Some of the representatives of the Federal Council of Churches were dissatisfied with the way Du Plessis was treated and felt that, although he was co-responsible for the negative outcome, his publications addressed issues, which needed to be discussed. These included, inter alia, the character of the DRC, the authority of Scripture, the historical-critical study of the Bible, creation and evolution, Jesus as a human being, missionary work amongst the indigenous people of Africa and the church's relationship with the state and broader society.

The conservative group took the initiative and addressed some of the issues in a trilogy called Koers in die Krisis (The Way Forward in the Crisis). Two of the editors, F.J.M. Potgieter (1907-1992) and J.D. Vorster (1909-1982), were theological students during the last few years of Du Plessis's tenure as professor and were witnesses to the theological skirmish. They, already then, associated with the conservatives and both played a leading role in promoting conservative theological and political viewpoints during their lifetimes (Potgieter 1961, 1978; Vorster 1978b). The three volumes of essays were published in 1935, 1940 and 1941 under the auspices of the 'Calvinist Student Organisations in South Africa' (Langer 2007:47-50), respectively. The claim to be a 'Calvinist' suddenly became all important during the post-Du Plessis years. This label professed that to be theological conservative was not synonymous with being a fundamentalist. However, the Calvinism that took root in the Afrikaans-speaking reformed churches during these years was from Dutch origin - more specifically Abraham Kuyper's interpretation of Calvin's theological viewpoints.

The triumph of the conservatives and their convictions concerning the Bible went hand in hand with three developments in the life of white Afrikaans-speaking citizens during these years: firstly, the revival of 'AfrikanerCalvinism'; secondly, the blossoming of Afrikaner nationalism and the apartheid policy and finally, the establishment and influence of a covert cultural organisation called the 'Afrikaner-Broederbond' (Afrikaner Brotherhood).

\section{Afrikaner-Calvinism}

Abraham Kuyper (1837-1920) was an influential Dutch theologian, politician, newspaper editor and academician. He was a co-founder of the Free University of Amsterdam in 1880 and taught theology there. His theological convictions led to the establishment of a new branch of the 'Hervormde Kerk Nederland' (Reformed Church in the Netherlands) in 1886. This group later joined another one, which severed its ties with the 'Hervormde Kerk' already in 1834. The two church groups then formed the 'Gereformeerde Kerke Nederland' (Reformed Churches of the Netherlands) in 1892 (Deist 1986b:117-119).

Kuyper was critical of the Enlightenment as it played out in France. According to him, the French Revolution (1789-1799) did not only remove the king but also removed God (Matisonn 2015:87). He therefore campaigned that the Dutch people should refrain from following suit and ban God from government, politics and social life. He argued for a Christian theocracy similar to what Calvin argued for (Kinghorn 1986a:60). Kuyper developed his ideas into a theological philosophy called 'sowereiniteit in eie kring' (sovereignty in own circle). The way in which the government gives expression to God's reign may differ from the way in which the church gives expression to God's reign (De Gruchy \& De Gruchy 2005:89). However, if Scripture served as guide - as it should - the different spheres of life will all give evidence to God's kingdom. His convictions became influential in South Africa as more Afrikaans-speaking theological students from the DRC studied at the Free University of Amsterdam or wrote theses about Kuyper's theology (Deist 1986b:36).

Reformed theologians in South Africa thus developed their own branch of Calvinism in association with Kuyper's views and labelled it 'Afrikaner-Calvinism' - sometimes even called 'Boer-Calvinism' (Langer 2007:49, 59, 61). This kind of Calvinism contributed to the negative outlook colonisers cherished concerning the indigenous people of South Africa. Kuyper was convinced that only the descendants of Noah's two sons, Shem and Japheth (Asians and Europeans), contributed to civilisation, whilst the descendants of Ham (Africans) failed dismally (cf. Salemink \& Van Dijk 1989:11). This conviction contributed to the belief in the superiority of the Christian religion. To be honest, all Europeans during those years believed that Christianity was superior to other religions and that Europeans were more civilised than the indigenous people of Africa who worshipped pagan gods (De Gruchy \& De Gruchy 2005:171-175; Salemink 1997:27-30). This superiority was also associated with skin colour. White European superiority went hand in hand with Christian superiority. Christian symbolism contributed to this discrimination since white is associated with 'purity, virtue 
and Christ' and black 'with impurity, evil and the devil' (Jablonski 2012:158).

European Christians believed that they had the task to convert the indigenous people and Christianise them. By doing this, Africans would become not only 'better humans' but also 'better citizens'. However, it was believed that African people had to form their own congregations and churches, which could influence the 'soul' of their respective nations. Separation for the sake of individual and national growth and development was believed to be the best missionary policy and practice. The missionary policy of the DRC, which the Federal Council adopted in 1935, evidences this kind of thinking (Kinghorn 1986b:87-90; Loubser 1987:29-33). But separation soon changed into segregation and eventually into apartheid (Vosloo 2015:196-200). Two reformed theologians played a leading role in this metamorphosis: Professor J.D. du Toit (Totius) from the Reformed Churches in South Africa (RCSA) and Professor E.P. Groenewald from the DRC.

Although Totius was not a member of the DRC, he was an influential theologian, poet, Bible translator and member of the Afrikaner Broederbond. He was a member of the Reformed Churches in South Africa (RCSA), which had close ties with the Reformed Churches of the Netherlands and Kuyper's theology. He read a paper at the Volkskongres ('People's Convention') held in Bloemfontein in 1944 with the title 'Die Godsdienstige Grondslag van ons Rassebeleid' (The Religious Foundation of our Race Policy). He claimed that the idea of segregation runs through the whole Bible (Kinghorn 1986b:101-102). He started with Genesis 1 and argued that God is the 'Great Divider' because this is his preferred method to create (Jonker 1998:193). The story concerning the building of the tower at Babel (Gen 11) served him well in arguing that the tower builders went against God's will in trying to remain a united nation with a single language. God intervened and dispersed them over the whole world. He continued and opined that God abhors the practice of equalising nations and races. God prefers diversity not uniformity (Loubser 1987:55-57; Snyman 2015:217-221; Vosloo 2015:196-200). Christians from different nations do experience unity, but it is a spiritual unity through Christ Jesus on account of the indwelling of the Holy Spirit (Gal 3:26-29). However, to try and make this unity a reality in this world will go against God's will. Totius was convinced that his theological views were in line not only with Kuyper's but also with Calvin's. Kuyper expressed similar viewpoints, however, which was more than 70 years ago and in a total different context from the South African one (Loubser 1987:41-45; Lubbe 2002:11).

\section{Afrikaner nationalism and the apartheid policy}

Apart from Totius' contribution to the biblical support for segregation and apartheid, he also contributed to the belief that the Afrikaners were chosen people similar to Israel. Their history in fact runs parallel to that of Israel. Did the Afrikaners not experience an exodus and a new settlement during and after the Great Trek from the Cape? The centennial commemoration of the Great Trek in 1938 and the inauguration of the Voortrekker Monument in 1949 contributed to a new wave of Afrikaner nationalism (Murray \& Stadler 1991:258-260; Welsh 2009:15). The Trek was seen as the Afrikaners' exodus and celebrating it after the Anglo-Boer War (1899-1902) gave new meaning to their history. Israel after all did not only experience an exodus but also experienced an exile. The exile was followed by a period of restoration and a new beginning. The Afrikaners were now experiencing a period of restoration. The AngloBoer War (1899-1902) was lost, but it acted as a catalyst in the growth of Afrikaner nationalism (Bosch 1984:22). The war with all its hardships and losses created a bond between the Afrikaners of the two republics (the Orange Free State and the Zuid-Afrikaanse Republiek) and those who lived in the Cape Province. It is therefore not strange that ministers referred to the acts of Nehemiah (Neh.13:1-3) and called on the Afrikaners to follow suit. They should not marry foreigners but cherish their identity. Their salvation lies in racial purity or better expressed racial apartheid.

During this period with the swell in Afrikaner nationalism, the DRC in the Transvaal established a theological faculty at the University of Pretoria. Proposal to establish such a faculty was submitted more than once at synod meetings prior to 1937. However, it was always turned down because the DRC in Transvaal did not want to jeopardise its relationship with the DRC in the Cape Province. Those who submitted the proposal motivated it by referring to the fact that the long distance students had to travel to Stellenbosch and the living costs for students. However, soon after the Du Plessis case, ministers of the DRC in Transvaal opined that the time had arrived to establish such a faculty at the University of Pretoria (Deist 1994:141-142; Van der Watt 1987:170-179). What is of interest is that five out of the six professors appointed at this faculty in 1938 completed their postgraduate studies at the Free University of Amsterdam (Loubser 1987:35). Professor E.P. Groenewald was one of them and he shared the convictions of his contemporaries Totius, F.J.M. Potgieter and J.D. Vorster. Moreover, he was also a member of the Afrikaner-Broederbond.

Groenewald was not only professor of New Testament at the faculty in Pretoria but also a representative of the Federal Council of the DRC in Transvaal, which met in 1943. He chaired the committee for Current Affairs and they received a request from the Federal Council to prepare a report concerning the biblical support for apartheid for the next meeting to be held in 1947. Groenewald submitted such a report and the Federal Council accepted it without any reservations (Van der Watt 1987:87-88). The report was eventually published with minor changes in the same year in the book Regverdige Rasse-apartheid (eds. Cronjé \& Nicol 1947). It now carried the title 'Apartheid en voogdyskap in die lig van die Heilige Skrif' (Apartheid and guardianship in the light of Holy Scripture) (Groenewald 1947:41-67). What soon transpired was that Groenewald was informed inter alia by a mini-dissertation of one of his students at the faculty 
when he wrote the report. The mini-dissertation titled 'Die beginsel van rasse-apartheid getoets aan die Nuwe Testament' (Adjudication of the principles of racial apartheid using the New Testament) was submitted in 1946 (Lubbe 2002:11-12). However, Totius' paper also lurked in the background because Groenewald referred to similar biblical texts to argue a case for separation and apartheid. However, contrary to Totius, he did not refer to Calvin and Kuyper. He focussed on biblical texts, which, according to his reading and exegesis, clearly communicated the ideas of separation, segregation and apartheid. His exegesis of the texts did not reflect a proper contextual and historical-critical reading. He read the Bible with preconceived ideas concerning the relationship between white people and black people.

Groenewald argued that the following 'principles' could be abstracted from the Bible: (1) Scripture teaches the unity of humanity (Acts 17:26). (2) Diversity, however, cannot be ignored because God created different human sexes, peoples, languages and races (Gn 1:26-29, Dt 32:8). (3) It is God's will that they should maintain their respective identities (Gn 11). (4) God blesses those who respect the laws and principles he established (Dt 7:11). (5) God eventually brings about a greater unity in Christ but this is a spiritual unity (G1 3:28, Eph 4:4-6, Rv 5:9). (6) Apartheid applies to all spheres of life: national, social and religious. (7) More developed nations have a responsibility towards the less developed ones (Jos 9, Gn 4:9, Mt 25:31-46, Gl 4:2) (Gaum 1997:7; Kinghorn 1986b:103-104; Loubser 1987:61-69; Lubbe 2002:12; Vosloo 2015:200-204).

The biblical texts which Groenewald quoted and discussed in his paper became all important for the DRC and served as proof texts to counter any criticism from either outside or inside the DRC. These biblical texts surfaced in report after report which the DRC issued after 1950 (Loubser 1987:78-79).

\section{The Afrikaner-Broederbond}

The Afrikaner-Broederbond (AB) was established in 1918 in the suburb Malvern in Johannesburg (Pelzer 1979:11). The aim was to promote unity amongst white Afrikaners of the reformed tradition; to foster love for the Afrikaner people, their language, history, traditions and their country and to promote Afrikaner education, arts and culture and economic development (Lückhoff 1978:25; Pelzer 1979:14-17). The organisation did not start as a secret organisation, but it soon developed into one. Secrecy eventually became of utmost importance to the organisation. Although it claimed that it never imposed its viewpoints onto other organisations (especially the reformed churches), it did promote convictions concerning apartheid as developed by reformed theologians and ministers because it believed that these convictions contributed to Afrikaner unity and were of utmost importance for their survival as a distinct group: 'Die Bond onderskraag die Christelike Afrikaanse Kerke om die Afrikanervolk as 'n Protestants-Christelike gemeenskap te bestendig en te versterk, en bestry veral enige Rooms-Katolieke aanslag op die Protestants-Christelike samestelling en karakter van die
Afrikanervolk' (Pelzer 1979:16). Quite a number of reformed theological professors and ministers became members of the organisation (cf. the lists in Wilkins \& Strydom 2012:A2-155) and played a leading role in developing biblical support for the apartheid policy. Amongst them were the ones already mentioned: E.P. Groenewald, F.J.M. Potgieter and J.D. Vorster. These DRC theologians became embroiled in cultural and political issues and their theological convictions reflected this (Hugo 1998:33, 42, 45; Jonker 1998:69-73; Smith 2009:64-73). This became crystal clear after the Cottesloe consultation of the WCC held in December 1960 (cf. pp. 6-7 below).

\section{Consolidation and criticism}

Groenewald's report, which had been accepted at the Federal Council in 1947, was ratified during the following 2 years by all four provincial churches although the DRC of the Transvaal and the DRC of the Cape Province expressed some reservation concerning a few of the principles. However, already by September1948, it became evident that the DRC accepted apartheid as a church policy and that it believed that its policy could serve the incoming National Party well (Gaum 1997:7-8; Loubser 1987:70; Lubbe 2002:32-33). There were, however, theologians and academics who criticised the way the Bible was used to convince others that separation and apartheid were important themes in the Bible (Van der Watt 1987:92-95). They also argued that the history of Afrikaners could not be equated with the history of Israel.

Professor Ben Marais was one of the first to vent his criticism (Vosloo 2015:205). At the synod meeting of the DRC in Transvaal in 1949, he argued that the exposition of the biblical texts in Groenewald's report is of a doubtful quality. He also opposed the view that the history of the Afrikaners runs parallel to the history of Israel and opined that one cannot take biblical verses from the Old Testament and apply them to the history of the Afrikaners. Israel was a religious unity not a racial unity. The surrounding people belonged to the same race as the Israelites. They were all Semites, but only Israel worshipped Yahweh. He developed his arguments properly in an article titled 'Die Skrif en rasseapartheid' (The Bible and racial apartheid) (Marais 1950:14-25).

Professor Pistorius from the department of Classics at the University of Pretoria came out in support of Marais. He convincingly argued that the texts from the New Testament do not communicate the message Groenewald was promoting. He emphasised that the DRC should refrain from seeking 'scriptural proofs for an already existing policy' (Loubser 1987:73). He wrote an article for the same journal as Marais and published his view under the title 'Ons apartheidsbeleid en die Skrif' (Our apartheid policy and Scripture) (Pistorius 1950:26-33). The editor of the journal, however, thought it fit to add E.A. Venter's article with the title 'Die Heilige Skrif en die apartheidsvraagstuk' (Holy Scripture and the quest of apartheid) (Venter 1950:5-13) to the same edition of the journal, evidently to give the conservatives a voice as 
well. He rehearsed the well-known arguments of those who read the Bible in a naïve way and who used Israel as an example for the Calvinistic Afrikaners. He also claimed that there were a number of overseas academics supporting the DRC's use of Scripture, but he refrained from supplying the names, thus, creating the impression that the pro-apartheid theologians did not stand alone.

As was the case with Marais, Professor B.B. Keet from Stellenbosch did not agree with Groenewald's report, which the synod of the DRC in the Cape Province had to ratify in 1949. However, he could not express his views at the synod meeting because he was not a representative of a congregation. He only attended the synod as a theological professor and an interested member. Soon after the synod meeting, he published four articles in Die Kerkbode in which he critically engaged the report (Keet 1949a, 1949b, 1949c, 1949d). As mentioned earlier, Keet studied at the Free University of Amsterdam. However, already during the Du Plessis case, he showed himself to be a man of great wisdom and one who did not let his emotions see the better of him. He warned the DRC not to go its own way in promoting apartheid and to abuse the Bible by claiming that it supported the policy. He opined that the DRC theologians were driven more by fear than by proper exegesis of biblical texts (Deist 1994:187; De Gruchy \& De Gruchy 2005:56-58).

The three academics published books as well to inform the broader public about their convictions. Marais published the book Colour: The Unsolved Problem of the West (1952), Keet the book Whither South Africa?(1956) and Pistorius the book No further trek (1957). The conservatives followed the suit and published the following books: Veelvormige ontwikkeling - die wil van God (Potgieter 1956) and Eiesoortige ontwikkeling tot volksdiens: die hoop van Suid-Afrika (Du Preez 1959).

The three academics were voices crying in the wilderness. They were not members of the Afrikaner-Broederbond and were swimming against the tide of Afrikaner nationalism and the belief that the arguments based on the Bible were well founded and aligned with Calvin. In the words of Loubser (1987:75): 'They were individuals without any real power base, facing a mighty tide of emotion and of upwelling nationalism'.

\section{Confrontations and reformulations (1960-1989)}

Towards the end of the 1950s, the four provincial DRC churches had reached consensus regarding the Bible and race relations. They were convinced that unity and diversity were important themes in the Bible. All humans have the same standing before God because he created all of them. However, God prefers that each nation should develop its own identity. The history of Israel evidences this. God prescribed separation as a way of living for Israel so that they could be a blessing to all humanity. He warned them not to marry foreign women lest they go astray and serve pagan gods. Because the history of Afrikaners runs parallel to that of Israel, they could learn from the Old Testament concerning relationships with other races and ethnical groups. The Afrikaners also have a calling. They should Christianise the indigenous people of South Africa and assist them in developing their own identity. However, events during the following two and a half decades challenged the DRC's convictions and policies (De Gruchy \& De Gruchy 2005:67-84).

\section{Sharpeville, the World Council of Churches and the South African Council of Churches}

The World Council of Churches (WCC) was established in the same year in which the National Party (NP) of D.F. Malan came into power in South Africa - 1948. Only two of the four provincial churches of the DRC became members of the WCC - the DRC of Transvaal in 1951 and the DRC of the Cape Province in 1953 (Van der Watt 1987:97). The DRC of the Orange Free State and the DRC of Natal wanted nothing to do with the ecumenical council because they regarded it as too accommodating and liberal. The stance of these two provincial churches soon affected the other two churches and they were forced to resign from the WCC and distance themselves from this ecumenical body. The following events led to this act.

On March 21, 1960, there was a protest march in Sharpeville, one of the black people townships of Vereeniging. The group protested against the pass laws of the government and marched towards one of the police stations to vent their frustrations. Things ran amok and 69 people were shot and killed by the police, whilst numerous were injured - either wounded or trampled upon during the stampede to escape (De Gruchy \& De Gruchy 2005:61; Frankel 2001:90-167; Lückhoff 1978:1). The event reverberated across the globe. The NP government proclaimed a state of emergency and appointed a commission to investigate what happened on that fateful day. The secretary-general of the WCC soon visited South Africa to meet leaders of the South African member churches. During follow-up meetings, it was decided that the eight Afrikaans- and English-speaking member churches would meet under the auspices of the WCC to discuss their mutual relationship and the crisis, which ensued following the Sharpeville massacre. They would also reflect on how they could improve the relationship between the different race groups in South Africa. This meeting, or consultation as it became known, was held from 7-14 December 1960 at the Cottesloe hostel of the University of the Witwatersrand (Lückhoff 1978:58-74). It was decided that each of the eight churches had to submit a memorandum on five issues, which they deemed important for the discussions. One of the five issues discussed in the memorandum of the DRC of the Cape Province focussed on race relations and Scripture (Lückhoff 1978:61). The memorandum stated that, inter alia, no Christian of whatever colour or race should be prevented from worshipping with other Christians; Christians from whatever colour or race may attend any church service and partake in Holy Communion in a 'white' people-dominated congregation; 
Scripture is not against mixed marriages and the state should not prohibit people from different races and colour to marry; all adult citizens of South Africa should be allowed to possess land and to partake in the government of the country.

The resolutions of the Cottesloe consultation (Lückhoff 1978:83-92) reflect that the memorandum of the DRC of the Cape Province played a definite role in the deliberations and in the wording of the resolutions (Gaum 1997:16-18; Strauss 2015:65). However, the resolutions were not well received by the Afrikaner press, the NP government and the Afrikaner-Broederbond (AB) (Lückhoff 1978:115-120). At least $50 \%$ of the two DRC provincial churches' delegates were members of the AB. They were called to task and criticised for deviating from the convictions of the $\mathrm{AB}$ and the three Afrikaans-speaking reformed churches (Pelzer 1979:83; Smith 2009:121-131; Van der Watt 1987:113-114). Following this, the DRC delegates reviewed their support for the Cottesloe resolutions, toed the line and re-joined the DRC-fold. Moreover, the two provincial churches (Transvaal and Cape Province) terminated their membership of the WCC for the sake of uniting with the other two provincial churches and the DRC of Southwest Africa (Namibia) to establish a general synod for the five DRC regional synods so that they could properly act as one church (Van der Watt 1987:109).

The Cottesloe consultation opened the door for the DRC to take leave of its ghetto-theology, to review its naïve reading of the Bible and to align itself with the larger Christian community. However, the DRC once again - as was the case with the Du Plessis case - made a tragic and fatal choice. 'It was now the prisoner of its own "apartheid bible"' (Loubser 1987:88). It would take another 30 years for the DRC to take leave of its theological convictions concerning race relations and the Bible.

One of the legacies of the Cottesloe consultation was the birth of the South African Council of Churches (SACC). Prior to the Cottesloe consultation, there existed a Christian Council that functioned as an interdenominational body that tried to foster better relations between the South African churches and missionary bodies, but it did not have a high profile. In 1966, it moved its head office from Cape Town to Johannesburg and in 1968, changed its name to the South African Council of Churches (De Gruchy \& De Gruchy 2005:113). It soon became the 'ecumenical' body in South Africa because more and more South African churches became members. The SACC and the WCC soon established a mutual relationship whereby the SACC kept the WCC informed about events in South Africa and the WCC assisted the SACC in its prophetical task. The DRC did not become a member of the SACC because it regarded its relationship with the two other Afrikaans-speaking reformed churches in South Africa (the RCSA and the Nederduitsch Hervormde Kerk van Afrika [NHKA]) as of more importance. Moreover, following the Cottesloe consultation and the break with the WCC, the DRC regarded the Reformed Ecumenical Synod (RES) and the World Alliance of Reformed Churches (WARC) as the more appropriate ecumenical bodies to be a member of. It probably believed that these bodies would better understand its convictions concerning the Bible and the way a church should engage the government of a country.

In the following years, the SACC became a thorn in the flesh of the NP government as well as the DRC because it kept on criticising the apartheid policy (or the policy of separate development as it was then called) and the DRC's theological support of it (De Gruchy \& De Gruchy 2005:112-123). In its publication Message to the People of South Africa published in 1968, the government came in for severe criticism. The NP government and the SACC were evidently on a collision track.

\section{Two DRC documents on human relations}

Already at the first meeting of the newly established General Synod of the DRC in 1962, a proposal was submitted that the synod should appoint a commission to formulate its theological viewpoint concerning the Bible and human relations because the previous Federal Council only acted as a co-ordinating body (Loubser 1987:89). A commission was appointed and a report prepared for the General Synod held in 1966. It was published as Human Relations in South Africa. The report was not well received and a revision was, therefore, requested (Strauss 2015:66). At the next General Synod held in 1970, the revised document was once again referred back for a second round of revisions. This fully revised and reworked document was accepted at the General Synod held in 1974 and published as Ras, Volk en Nasie en Volkereverhoudinge in die lig van die Skrif (RVN 1975). The document was soon translated into English, Dutch and German and sent to local and overseas church bodies with the request to engage and criticise the document (Du Toit et al. 2002:61-64; Van der Watt 1987:115-116). The DRC did not want to create the impression that it was not willing to listen to other Christians.

Soon after its publication, five South African theologians engaged the report and highlighted the inconsistencies, misinterpretations and illogical reasonings. Two of them focussed more on the problematic use of biblical texts, whilst the other three addressed hermeneutical, systematical and ethical issues. The five were: Vorster (1983:94-111), Durand (1978:3-11), van Wyk (1976:98-109), Johanson (1975:51-61) and Bax (1983:112-143). The latter two, however, were not members of the DRC.

The first section of RVN concerned the hermeneutical principles and biblical texts, which guided the commission in formulating its viewpoints (RVN 1975:5-38). However, this section did not reflect knowledge of recent scholarly discussions concerning the authority and interpretation of the Bible. The commission could have benefitted from reading Barr's book The Bible in the Modern World (1973). Concerning the biblical texts that were discussed, the wellknown texts, which Totius and Groenewald already referred to, (Gn 1, Gn 10-11, Dt 32:6, Ac 2:3-13, Ac 17:26) 
were once again discussed. This time round, the members of the commission tried their best not to read the texts in a naïve way. However, the discussion of sections from Genesis 1-11 evidenced that they did not properly distinguish the literary genres they were interpreting. Concerning such an error, Coats (1985:10) says: 'To make false assumptions about genre can lead to gross misunderstanding'. The DRC document reflects that the narratives were read as if they were historical accounts of real events that happened long ago (Vorster 1983:105). This led to dubious conclusions. However, the commission was in a Catch-22 situation. It could not deviate from former interpretations because that would undermine the longstanding DRC argument that unity and diversity were important themes in the Bible and that it supported separation and segregation. Moreover, if the commission came to the conclusion that the narratives concerning creation, Cain and Abel, Noah and his sons and the Tower of Babel were not historical accounts, then the DRC's argument concerning human relations and apartheid (or separate development) would fall flat (Deist 1994:189).

\section{The Soweto uprising and the third generation of DRC biblical scholars}

June 16, 1976 will always be remembered in South Africa as the day when black school children from Soweto (the townships southwest of Johannesburg) marched in protest against the compulsory use of Afrikaans to teach secondary school black children (Morris 2012:106). This policy was introduced by Andries Treurnicht (a former DRC minister and staunch supporter of the apartheid policy) after becoming the new Minister of Education. The protest soon grew into a revolt against the apartheid system as protestors in almost every town joined in and marched towards police stations or civic centres. Shops and liquor stores were looted and the police once again had to step in to enforce law and order. On July 6 , the government scrapped the compulsory teaching of Afrikaans in black schools, but it took many months before calm returned. The journalist Morris (2012) is correct in linking the Sharpeville massacre and the Soweto uprising:

As Sharpeville redefined the political contest of the 1960s, turning protest against discrimination into an armed struggle for national liberation from minority rule, so did the Soweto uprising a decade and a half later reinvigorate the struggle, as well as ushering in a phase of low-level civil war in which townships eventually became battle zones, patrolled by armed troops and revolutionary-minded 'comrades'. (p. 109)

It was evident that the frustration of black people was at a breaking point (De Gruchy \& De Gruchy 2005:164-165). But as a new generation of protestors and liberators entered the scene, a new generation of DRC biblical scholars entered the academy. Two of them became very prominent - Willem Vorster (1941-1993) and Ferdinand Deist (1944-1997). Both were well-acquainted with the historical-critical study of the Bible and both were accused of heresy early in their academic careers but were eventually acquitted (Spangenberg 1998:540-546).
Deist was accused of heresy on account of what he had written in his book Die Noodlottige Band: Kerk en staat in OudIsrael (1975). Read between the lines, the book critiqued the DRC's relationship with the NP government. He published his response to the accusations in the same year in which the Soweto uprising erupted and stated that the 'most elementary question in hermeneutics is: what is the Bible and not: how should I understand the Bible'?(Deist 1976:8-9). ${ }^{2}$ He answered the first question by arguing that the Bible consists of different literary genres and emphasised that the Bible does not narrate history from Genesis to Revelation as is often assumed. These different genres were written by people who lived in a totally different environment and cherished different convictions than we do.

Willem Vorster delivered his inaugural lecture in 1977 and advocated similar viewpoints as Deist. However, he was less concerned with the historical-critical methods of reading the Bible and focussed more on reading the Bible as literature. He emphasised that the New Testament books were written by humans for humans and that they should be read and interpreted in the way that ordinary literature is read and interpreted (Vorster 1977:5, 1988:13, 26-27).

Both scholars were well trained and well versed in their respective fields: Deist as Old Testament scholar and Vorster as New Testament scholar. Neither of them belonged to the Afrikaner-Broederbond and became extremely critical of how the Bible was read and interpreted by theologians of the DRC. But they soon critiqued the way that the Bible was used by the anti-apartheid theologians as well. These theologians' use of the Bible mirrored that of the apartheid theologians. The pot could thus not call the kettle black - therefore, both groups should reflect on their claim that they were obediently listening to God (Deist 1983:79-108, 1986b:100-116; Lombaard 2001:77; Vorster 1984:2004-2219).

When these biblical scholars' convictions concerning the Bible are compared with the convictions of Heyns (1973a, 1973b) and Jonker (1975) - their contemporary DRC systematic theologians - it becomes crystal clear that they did not see eye to eye. The systematic theologians first construct a doctrine concerning the Bible and then read the biblical books keeping the doctrine in mind. The biblical scholars, on the other hand, first read the biblical books and then formulate theological statements keeping what they have read in mind. Moreover, the biblical scholars were no more convinced that one can claim to 'hear' the voice of God when reading the Bible. They do not hear God's voice; they only hear a crowd of human voices coming from different periods in the history of Israel and the early Christianity. It is now evident that two different convictions concerning the Bible once again entered the theological playing field. The biblical scholars aligned themselves with the statement of Barr (1973:142):

The Bible is not in fact a problem-solver. It seems to me normal that the biblical material bears upon the whole man, his total faith and life, and that out of that faith and life he takes decisions as a free agent. (cf. Deist 1976:27-31; Vorster 1977:1-2)

2.The italics are part of the original statement. 


\section{A call for church unity}

The missionary work of the DRC led to the establishment of three churches: (1) the 'NG Sending Kerk' (NGSK, for coloured people), (2) the 'NG Kerk in Afrika' (NGKA, for black people) and (3) the Reformed Church of Africa (RCA, for people of Indian descent). During the 1970s, the three 'daughter' churches started campaigning for unification with their 'mother' church (Du Toit et al. 2002:147). They reasoned that if the five regional 'white' people churches could become one by establishing a general synod in 1962, it should be possible to establish an overarching synod to unite the 'mother' church with the three 'daughter' churches that came into being, thanks to the missionary work of the DRC. The four churches represent the four racial groups as defined by the NP government. The conservatives in the DRC reacted by publishing nine essays in the book Veelvormigheid en eenheid (Diversity and unity) (Vorster 1978a) in which they argued that neither the New Testament (Botha 1978:5-8), nor Calvin and Kuyper (Potgieter 1978:11-18, 27-31), nor the missionary policy of the DRC (Van Heerden 1978:47-59) supported such an idea. A group of 18 theologians stepped forward and argued a case for church unity and an overarching synod. These essays were published in a book titled Die eenheid van die kerk (The unity of the church) (eds. Meiring \& Lederle 1979). Some of the authors even engaged the arguments of those responsible for the book Veelvormigheid en eenheid. Previously, Bosch convincingly argued that church unity was not a luxury but a powerful Christian testimony to the world (Bosch 1983:24-38). In the meantime, the three 'daughter' churches gained observer membership of the SACC, the NGSK in 1975, the NGKA in 1978 and the RCA in 1980 (De Gruchy \& De Gruchy 2005:192-193).The relationship between the DRC and the three churches thus became more strained.

In the late seventies, it was evident that the DRC was heading for a crisis. The younger generation of theologians and biblical scholars who were not members of the AfrikanerBond were becoming frustrated with its stubbornness in clinging to outdated convictions. ${ }^{3}$ It was not only the DRC that was heading for a crisis but also the NP government and the Afrikaner-Broederbond. In this dark hour, a philosopher at the university of Stellenbosch (cum member of the $\mathrm{DRC}$, cum member of the $\mathrm{AB}$ ) stepped forward and published a book titled Afskeid van Apartheid: Opstelle oor rassediskriminasie (Farewell to apartheid: Essays concerning racial discrimination) (Esterhuyse 1979). Looking back, one may call Esterhuyse a herald of the change that was coming. ${ }^{4}$

\section{The eighties: a decade of crises}

The penultimate decade of the second millennium was an extremely violent one. ${ }^{5}$ The DRC became more and more isolated whilst political violence escalated (Welsh 2009:208-343).The isolation of the DRC commenced with the church severing its ties with the Reformed Churches of the 3.The 123 petitioners of the "Open Letter" in 1982 may serve as an example. 4.Esterhuyse later had clandestine meetings with the ANC in Britain and played a role in the 'talks about talks' prior to the unbanning of the ANC and at the start of the negotiations (Esterhuyse 2012:83-105; Sparks 1994:76).

5.Welsh (2009:208) calls it 'The Turbulent Eighties'.
Netherlands (RCN)in 1978 because of the latter's support of the WCC's Program to Combat Racism (Du Toit et al. 2002:198202; Strauss 2015:69). This was followed by the WARC's suspension of the DRC's membership at its meeting in Ottawa in 1982 (Du Toit et al. 2002:152). The WARC stated that a status confessionis had developed concerning the DRC's theological support of the apartheid policy and that it had no other option than to suspend the DRC's membership until such a time that the DRC revised its theological stance (Botha \& Naudé 1998:33-34; De Gruchy \& De Gruchy 2005:193; Welsh 2009:190). At this meeting, Allan Boesak of the NGSK was unanimously elected as the new president of the WARC. The NGSK then followed suit and declared a status confessionis at its Synod in 1982 concerning the DRC's theological support of apartheid. A proposal was subsequently submitted that the Synod should appoint a commission to write a confession that could express the NGSK's beliefs on why it was convinced that the apartheid policy contradicted the Christian gospel of reconciliation. A draft confession was already accepted during the meeting, but the synod requested a revision (Botha \& Naudé 1998:34-37). At the next synod meeting held in 1986, the NGSK approved the wording of the new confession and named it 'The Belhar Confession' (Botha \& Naudé 1998:56-57). In 1984, the Reformed Ecumenical Synod (RES) requested the DRC and the GKSA to look at their theological and biblical support of the policy of apartheid and separate development once again and report back to the RES at its next meeting (Du Toit et al. 2002:217-221).

By the middle of the eighties, the DRC had become a pariah church whose acts and policies were seen by others as bordering on racism. It, thus, had to do some serious reflection concerning its theological conviction that the Bible is proseparation and that the gospel does not require Christians from different races, cultures and colour to become members of the same church. However, it was realised that a revision of RVN required a revision of its view and interpretation of the Bible. At the General Synod of 1986, a new document was tabled concerning the DRC's view of Scripture (Potgieter 1990:59). The document evidences a move away from a naïve understanding of what the Bible is and how one should read and understand it. However, the DRC was neither willing to fully embrace the historical-critical methods of studying the Bible nor the literary approaches of reading it. It was willing to leave room for these kinds of methods and approaches as long as they did not undermine the authority of the Bible and the conviction that God is the prime author (auctor primarius) thereof (Potgieter 1990:63-64; Spangenberg 2002b:184-187). Moreover, the DRC adhered to the belief that the Old and the New Testament form a unity and that the New cannot be understood without the Old and vice versa. It was also not willing to sacrifice the belief that the Bible remains its own interpreter (scriptura sui ipsius interpres) (Potgieter 1990:61). The $\mathrm{DRC}$, thus, tried to merge a conservative and a more progressive view concerning the Bible.

During the Synod meeting, the DRC also accepted a new document called Kerk en Samelewing (Church and Society), which deviated substantially from the old RVN of 1974. In 
the new policy document, the DRC took leave of the conviction that the Bible supports separation and apartheid. Reading the document today leaves one with the impression that the DRC eventually accepted the resolutions of the Cottesloe consultation. However, it did so a quarter of a century later, whereas it could have performed so earlier (Du Toit et al. 2002:155-157). A number of delegates were not willing to accept the new policy document, eventually severed their ties with the DRC, and established a new church called 'Die Afrikaanse Protestantse Kerk'. Some theologians regard this as a tragic but inevitable event (Jonker 1998:192-195). However, for the DRC to move forward, it could no more be a 'broad' Afrikaans-speaking reformed church with room for those who are opposed to change.

At the close of the eighties, it was evident that the DRC did some serious soul searching. It took leave of its naïve way of reading and interpreting the Bible concerning race relations that guided it since the 1930s. It could rehabilitate itself in the eyes of the reformed and ecumenical world. However, the report concerning Scripture evidences that it still could not whole-heartedly embrace the paradigm change, which occurred towards the end of the 19th and the beginning of the 20th century (cf. pp. 1-3 above). It could not take the bold step which Barr (1980) formulated as follows:

Firstly, we have to build a doctrine of scripture 'from below' and not 'from above': we should read it for what it itself is and what it itself says, and avoid reading into it 'the evangelical doctrine of scripture', that is, the opinions that some people in evangelical Protestantism held about the Bible two centuries or so ago. (p. 88)

The DRC tried to embrace a doctrine 'from below' and 'from above'. It probably hoped that its revised view of Scripture would help church members understand the DRC's turnabout concerning the apartheid policy. However, it was not successful in appeasing those members who clung to the status quo.

\section{The DRC, the Bible and the new South Africa (1990-2020)}

In one of its publications, TIME magazine labels 1989 as 'The year that defined today's world' (ed. Elliott 2009). One of the articles concerned the meeting on 05 July 1989 between President P.W. Botha and Nelson Mandela in the former's official residence in Cape Town. In his short reflection, Perry (2009:54) wrote the following: [On that day] '... a whitesupremacist President and a black revolutionary leader took the first steps towards peace'. Few people knew about the secret talks that were conducted between some NP ministers and leaders of the ANC during the eighties (Sparks 1994:21-36) and fewer knew that $A B$ leaders were also involved in these talks (Esterhuyse 2012:106-134, 321-335). Both the NP and the $A B$ realised that the country was heading towards a full-blown civil war if negotiations with the ANC and other liberation movements did not start soon. These talks eventually led to the NP's sacking of the stubborn P.W. Botha and the appointment of F.W. de Klerk (Sparks 1995:91-108). On 02 February 1990, De Klerk announced the release of all political prisoners and the start of serious negotiations for a better future (Davenport 1998:9; Welsh 2009:382). The last decade of the second millennium brought about major political and ecclesiastical changes in South Africa.

\section{The ordination of women}

The General Synod of the DRC, which met in Bloemfontein in 1990, will be remembered not only for the revised version of the report Kerk en Samelewing (Church and Society) in which it finally took leave of apartheid (Jonker 1998:195-198) but also for the bold step it took in approving the ordination of women (Spangenberg 1993:124-125). There was an ironical twist to this resolution. One of the theological professors at the University of the Orange Free State - located in Bloemfontein - argued a case in his inaugural lecture in1983 that the Bible does not approve of women being ordained as elders or ministers (Kleynhans 1983). ${ }^{6} 7$ years later, the General Synod voted against this learned argument. The 'new' view of Scripture, which the DRC adopted at the General Synod of 1986, probably played a role in the resolution. However, this act emphasised that there will always be a tug-of-war between two groups in the DRC: those who embrace the doctrine of scripture 'from below' and those who are more at home in the doctrine of scripture 'from above' (Britz 2002:354-367; Doubell 2004:39).

\section{The Rustenburg consultation, the REC, the WARC and the URCSA}

The DRC's document Kerk en Samelewing (Church and Society), which was accepted at the General Synod of 1986, was - on request - revised and submitted at the General Synod held in Bloemfontein in 1990. However, prior to this synod meeting, a few delegates of the DRC met with other church leaders in March 1989 under the auspices of the REC (Reformed Ecumenical Council) $^{7}$ in Vereeniging to discuss the differences that existed between the DRC and its 'daughter' churches (NGSK, NGKA and RCA) concerning the apartheid laws and church unity. The delegates were not able to find some middle ground concerning the government's discriminatory and oppressive laws, but the Vereeniging consultation (as it came to be known) agreed to work together towards establishing a united non-racial reformed church in Southern and Central Africa. The DRC's delegates, however, expressed their sincere apology for the DRC's support over many years of the apartheid ideology and the pain and suffering which it caused $(\mathrm{Du}$ Toit et al. 2002:162-164). At the General Synod in Bloemfontein, the DRC's delegates to the Vereeniging consultation reported back and the synod fully agreed with the viewpoints expressed by the DRC's delegates. It was now evident that the DRC made an about-turn, took leave of its theological support of the apartheid policy and was willing to accept

6.The DRC approved the establishment of a third theological faculty at the University of the Orange Free State in 1982.

7.The Reformed Ecumenical Synod (RES) changed its name to the Reformed Ecumenical Council (REC) in 1988. 
co-responsibility for what went wrong in the South African society. On the basis of these apologies, Jonker took the initiative at an inter-church meeting held in Rustenburg (November 1990) to confess his and the DRC's sin for supporting the apartheid policy and for causing pain and suffering to others (De Gruchy \& De Gruchy 2005:210-211). He was not a DRC delegate but was requested to read a paper at the meeting. However, he felt himself convinced as a Christian to act in this way directly after reading his paper. This act caught the other churches' delegates totally off-guard. Some accepted the confession of sin and Desmond Tutu embraced the act of Jonker and offered forgiveness (Gaum 1997:54-55). Others remained sceptical. However, Pieter Potgieter, who was elected as the moderator of the General Synod in Bloemfontein few months earlier and who was a proper DRC delegate, stepped forward and approved the act of Jonker stating that it was aligned with the resolutions of the General Synod held in Bloemfontein (Jonker 1998:199208). This act of Jonker had a positive effect on the Rustenburg consultation and changed the views of many South African churches concerning the DRC (Gaum 1997:58-60). It probably also had a positive effect on the REC's stance because at its meeting in 1992 in Athens, it welcomed the DRC back into the fold (Du Toit et al. 2002:233). However, it took some time before the WARC followed the suit and welcomed the DRC back. This happened in 1998 (Du Toit et al. 2002:238-239).

In 1994, the NGSK and the NGKA united and named the new church the Uniting Reformed Church of Southern Africa (URCSA) with the hope that the RCA and the DRC would soon join so that the DRC could become a properly united reformed church in Southern Africa. The logo of the URCSA, thus, has a broken circle that evidences this hope.

\section{The deaths of Vorster, Deist, Heyns and Jonker and a new generation of scholars}

Serious negotiations between the different political parties soon commenced at the World Trade Centre in Kempton Park. The different parties agreed to start with a process of consultation and negotiation aimed at the establishment of a new constitution for the Republic of South Africa (Davenport 1998:10-13). Whilst the process was ongoing, the New Testament scholar, Willem Vorster, died (1993). A few months after the first democratic elections in 1994, Johan Heyns was murdered (05 November 1994). Three years later in 1997, the Old Testament scholar, Ferdinand Deist, died in Germany whilst on study leave. Twelve years after Heyns' tragic death, Willie Jonker died (2006). Within a period of 13 years, the DRC lost two of its prominent systematic theologians and two of its proficient biblical scholars (Spangenberg 1998:540-546). ${ }^{8}$

A younger generation of theologians and biblical scholars took over the baton and kept theology and biblical studies alive in the DRC and in the new South Africa. However, the different views concerning the Bible remained alive. The publications of

8.There were other tragic deaths as well. Willem Prinsloo, an Öld Testament scholar at the University of Pretoria, died in the same year as Deist (1997), and Hannes Olivier, an Old Testament scholar at the University of Stellenbosch, died the following year (1998). the younger generation evidence this. Quite a number of books and articles concerning the authority and interpretation of the Bible were published during the first two decades of the new millennium. The following may serve as examples.

Ben du Toit published a book in 2000, which is almost similar to Philip Kennedy's book A Modern Introduction to Theology: New questions for old beliefs (2006). He discusses the challenges which the new scientific knowledge poses for traditional beliefs. Chapter two concerns the Bible (Du Toit 2000:63-92). However, throughout the book, he keeps on emphasising that the Bible belongs to a pre-scientific world and that this fact creates problems for Christians living with a scientific worldview: 'Die Bybel is 'n premoderne bundel geskrifte' (Du Toit 2000:79). 'Ons het in die Bybelse geskrifte te doen met die persepsies en interpretasies van premoderne mense' (Du Toit 2000:147). Izak Spangenberg applied Thomas Kuhn's ideas of paradigms and paradigm changes to the study of the Bible. According to him, there were two major paradigm changes since the Protestant Reformation of the 16th century (Spangenberg 2002a:11-34). On grounds of the paradigm changes, he argues that it is possible to identify at least three ways of viewing the Bible: (1) the Bible as Word of God, (2) the Bible as Word of God written by humans and (3) words written by humans about God. These different views affect how people read and understand the Bible. These scholars, like many others, are no longer at home in the traditional reformed understanding of the Bible. They evidently work with a 'doctrine of scripture "from below"'.

Dirkie Smit revised and reworked a previous publication concerning the Bible (Smit 1987). The new and elaborate book was published in 2006 with the title Neem, lees! Hoe ons die Bybel hoor en verstaan. He applies Paul Ricoeur's ideas to the reading and understanding of the Bible (Smit 2006:114, 121, 126, 152). According to Ricoeur (1913-2005), a text has three worlds: (1) a world behind the text, (2) a world of the text and (3) a world in front of the text. Smith merges these ideas with the traditional reformed view of Scripture and concludes that through all the ages, the Christian God kept on communicating with Christians by means of the Bible: 'Dieselfde lewende God praat in sy trou vandag nog met ons, lewend, deur die lees en deur die luister' (Smit 2006:53). Louis Jonker, Ernst Conradie and Jan Botha gave permission that their book Die Bybel in Fokus: Hoe om krities en gelowig te lees may be republished but with a slightly different title: Die Bybel in Fokus: Hoe om gelowig én denkend te lees (2020). In their book, they argue along similar lines as Smit. They are still convinced that a responsible reading will help readers in hearing God's voice coming to them through the Bible. The heading of the last chapter has the title 'Hoe kan ons weer God se stem in die Bybel hoor'? [How are we able to hear God's voice again in the Bible?]. These scholars try to remain as close as possible to the traditional reformed understanding of the Bible and therefore, one may conclude that they are still working with a 'doctrine of scripture "from above"'.

A number of shorter articles were also published in which the different authors tried to explain how the Bible should be 
read and interpreted in a reformed church. Others focussed more on what the current situation in the DRC is concerning the authority of the Bible and how the post-apartheid context is affecting the reading thereof. A few references should suffice.

Fanie Snyman, an Old Testament scholar from the University of the Orange Free State, made a correct assessment of the situation in DRC by stating: 'Daar is in die Ned Geref Kerk ook nie 'n eenduidige Skrifbeskouing nie. Skrifbeskouing in die Ned Geref Kerk wissel van 'n fundamentalistiese Skrifbeskouing tot ' $n$ meer kritiese benadering tot die Bybel' (Snyman 1998:13). His colleague, Rudolph Britz, however, is of the opinion that there are two prominent opposing views concerning the Bible and that these views are creating a dilemma that needs to be addressed (2002:354-367). Their New Testament colleague argues that the Bible is primarily given not to be dissected but to assist in spiritual growth. One may analyse the Bible critically but that should only be an intermediate phase. One should move from this stage to a second one whereby one once again embraces the Christian message. He adopts Paul Ricoeur's conviction that one should move from a 'first naïveté' via being critical to a 'second naïveté' (Van Zyl 2001:87). Annes Nel opines that the DRC's claims about the Bible during the apartheid-era were far too high - almost as if the DRC alone could hear God's voice. This contributed to church members' scepticisms following its turnabout in 1990. The church should rather embrace the view that the Bible is God's Word written by humans who lived centuries ago in a totally different context from ours. It does not communicate eternal truths but contextual truths. Had the DRC performed so, church members would have understood the turnabout concerning the apartheid policy ( $\mathrm{Nel}$ 2003:122-132).

\section{The Bible and homosexuality: Resurging of fundamentalism?}

The DRC's turnabout concerning the apartheid policy and the ordination of women at its General Synod in 1990 created the hope that it would also reconsider its policy concerning people with a homosexual orientation. At that stage, most ministers of the DRC were convinced that homosexuality is an aberration and that people with a homosexual orientation should receive pastoral care and guidance to become 'normal human beings'. The DRC's report concerning this issue was based on a publication prepared by Albert Botha for the General Synod's Youth Commission (Botha 1980).The DRC's policy was more or less aligned with the convictions of psychologists (Bartlett 2017:17-26). However, research into human evolution and genetics since then revealed that homosexual relations are not abnormal. Human sexuality is far more complex than what was 'common knowledge' in the seventies and eighties.

After the change in government in 1994, homosexual relations became a burning issue for all churches because the new constitution - which is based on the Universal Declaration of Human Rights - outlaws discrimination based inter alia on sexual orientation. The DRC has always tried to treat people with a homosexual orientation with respect and dignity, but it was now confronted with the issue of 'gay marriages' and the ordination of 'gay people' as elders and ministers in the church. This led to heated debates in the church since the turn of the millennium. What soon transpired was that those church members and ministers cherishing conservative views of Scripture believe that God does not approve of such relationships let alone approve gay marriages and their ordination as ministers. The following texts usually serve as evidence that God abhors such relationships: Genesis 19:5-9, Leviticus 18:22, Leviticus 20:13, Judges 19:16-26, Romans 1:18-2, 1 Corinthians 6:9-10 and 1 Timothy 1:9-10. However, those church members and ministers who adhered to a more progressive view of Scripture took a different stance on this issue. They emphasised that the seven texts should be read and interpreted in their cultural contexts (Anthonissen \& Oberholzer 2001:121-140).

At its General Synod held in 2007, the DRC approved that people with a homosexual orientation may be ordained but should remain celibate. Not all delegates approved of the resolution (Bartlett 2017:115-131). The synod, therefore, requested that the commission concerned with the issue should do much research to assist the DRC in formulating a policy acceptable to all. Two synods later in 2015, the General Synod approved gay 'marriages' although that was not labelled a 'marriage' but only a 'civil partnership' (Bartlett 2017:185-203). Again, not all delegates approved of the resolution and number requested a revision. This revision was tabled at a special General Synod held in 2016. The resolution of 2015 was recalled and the church had to revert to the resolution of 2007. However, some congregations were of the opinion that the special General Synod was not constituted properly and took their case to a civil court and won. The resolution of 2015, therefore, remained intact (Oosthuizen 2016). However, at the General Synod of 2019, the DRC formulated a new policy on this issue. It resolved that because there exist different opinions concerning the authority of the Bible on the issue, each congregation should decide how it will treat its homosexual members. This resolution was seen by many as a cop out.

The situation in 2020 is, thus, similar to the one in the 1930s as well as in the 1960s of the previous century. It remains difficult to convince ministers and ordinary church members of the paradigm change, which occurred towards the end of the 19th and the beginning of the 20th century concerning the Bible, and to reformulate their view of Scripture. Some Christians cannot embrace the idea that the Bible is the Word of God written by humans, let alone that the Bible is a collection of human words about God. For them, the Bible remains the Word of God - sometimes in an almost literal sense.

\section{Conclusion}

Looking back over a period of a 100 years, it becomes evident that the DRC is still struggling to embrace the paradigm change that occurred towards the end of the 19th and the beginning of the 20th century in the field of biblical studies. 
Over the years, different Synods have been struggling to formulate a doctrine of Scripture aligned with it but without success. One is tempted to say that had the DRC embraced the new paradigm during the 1930s, its history of support for the apartheid policy and it history of anti-gay convictions a century later, might have looked totally different. However, the history of the DRC in the past century also reflects that a fundamentalistic understanding of the reformed principle of sola scriptura will for ever remain an obstacle for reformed churches trying to be institutions where people are not discriminated against, whether they are male or female, rich or poor, white or black and homosexual or heterosexual. As long as church members believe that the Bible is the Word of God and as long as theologians and ministers are beating about the bush and refrain from stating unequivocally that the principle of sola scripture is outdated and that there is a need for a totally new understanding of the Bible, there will be differences of opinion and theological skirmishes.

\section{Acknowledgements}

The author would like to acknowledge Dr Andries F. Conradie who read this manuscript and made valuable comments.

\section{Competing interests}

The author declares that no competing interests exist.

\section{Authors' contributions}

The author is solely responsible for this article and its content.

\section{Ethical consideration}

This article followed all ethical standards for a research without direct contact with human or animal subjects.

\section{Funding information}

This research received no specific grant from any funding agency in the public, commercial or non-profit sectors.

\section{Data availability statement}

Data sharing is not applicable to this study as no new data were created or analysed in this study.

\section{Disclaimer}

The views and opinions expressed in this article are those of the author and do not necessarily reflect the official policy or position of any affiliated agency of the author.

\section{References}

Anthonissen, C. \& Oberholzer, P., 2001, Gelowig en gay? Riglyne vir 'n sinvolle dialoog met gay lidmate in die gemeente, LuxVerbi.BM, Wellington.

Barr, J., 1973, The Bible in the modern world, SCM, London.

Barr, J., 1980, The scope and authority of the Bible, SCM, London.

Bartlett, A., 2017, Weerlose Weerstand: Die gaydebat in die NG Kerk, Protea Boekhuis, Pretoria.
Bax, D., 1983, 'The Bible and apartheid 2', in J.W. De Gruchy \& C. Villa-Vicencio (eds.), Apartheid is a heresy, pp. 112-143, David Philip, Cape Town.

Bosch, D.J., 1983, 'Nothing but a heresy', in J.W. De Gruchy. \& C. Villa-Vicencio (eds.), Apartheid is a heresy, pp. 24-38, David Philip, Cape Town.

Bosch, D.J., 1984, 'The roots and fruits of Afrikaner civil religion', in J.W. Hofmeyr \& W.S orster (eds.), New faces of Africa: Essays in honour of Ben (Barend Jacobus) Marais, pp. 14-35, Unisa, Pretoria.

Bosch, D.J., 1986, 'Johannes du Plessis as sendingkundige', Theologia Evangelica (SA) 19(1), 66-76.

Botha, A., 1980, Pastorale Sorg aan die Homoseksueel, NG Kerk Jeugboekhandel, Bloemfontein.

Botha, F.J. (Frikkie), 1978, 'Die eenheid van die kerk by Johannes', in J.D. Vorster (ed.), Veelvormigheid en Eenheid, pp. 5-8, NG Kerk-Uitgewers, Kaapstad.

Botha, J. \& Naudé, P., 1998, Op pad met Belhar: Goeie nuus vir gister, vandag en môre!, J.L. van Schaik, Pretoria.

Britz, R.M., 2002, 'Twee standpunte oor die Skrif ... en 'n dilemma vir die NG Kerk', NGTT 43(3\&4), 354-367.

Coats, G.W., 1985, 'Genres: Why should they be important for exegesis?' in G.W. Coats (ed.), Saga, Legend, Tale, Novella, Fable: Narrative forms in Old Testament literature, pp. 7-15, JSOT Press (JSOTS 35), Sheffield.

Cronjé, G. \& Nicol, W. (eds.), 1947, Regverdige Rasse-Apartheid, CSV, Stellenbosch.

Davenport, T.R.N., 1998, The transfer of power in South Africa, David Philip, Cape Town.

De Gruchy, J.W. \& De Gruchy, S., 2005, The church struggle in South Africa, 25th Anniversary edn., Fortress, Minneapolis, MN.

Deist, F.E., 1976, Historiese Heuristiek, Teologiese Hermeneutiek en Skrifgesag, Universiteit van Port Elizabeth, Port Elizabeth.

Deist, F.E., 1983, Verandering sonder geweld? Tafelberg, Kaapstad.

Deist, F.E., 1986a, 'Die wa van Ussa ofte wel Johannes du Plessis en die belydenisskrifte', Theologia Evangelica (SA) 19(1), 36-65.

Deist, F.E., 1986b, Kan ons die Bybel dan nog glo? Onderweg na 'n Gereformeerde Skrifbeskouing, J.L. Van Schaik, Pretoria.

Deist, F.E., 1987, 'Relatiwisme en absolutisme: Kan dit oorkom word? Oor "Bybelse" en "Dogmatiese" teologie', in W.S. Prinsloo \& W. Vosloo (reds.), Ou Testament Teologie: Gister, vandag en môre, pp. 1-17, NG Kerkboekhandel, Pretoria.

Deist, F.E., 1988, 'Naïewe realisme en Ou-Testamentiese wetenskap in die Nederduitse Gereformeerde Kerk', in W.S. Prinsloo \& W. Vosloo (eds.), In Mensetaal oor God se Woord: Huldigingsbundel opgedra aan professor A.H. van Zyl, pp. 23-32, Lux Verbi, Kaapstad.

Deist, F.E., 1994, Ervaring, Rede en Metode in Skrifuitleg: 'n Wetenskapshistoriese ondersoek na Skrifuitleg in die Ned. Geref. Kerk 1840-1990, RGN, Pretoria.

Doubell, F.B., 2004, 'Die Bybel steeds in diskussie: 'n Dekade later', Acta Theological Supplementum 6(1), 31-48.

Du Plessis, J., 1923, 'Wat was "het teken van Jona"?' Het Zoeklicht 1(1), 213-217.

Du Preez, A.B., 1959, Eiesoortige ontwikkeling tot volksdiens: die hoop van Suid-Afrika, HAUM, Kaapstad.

Durand, J.J.P., 1978, 'The Bible and race: The problem of hermeneutics', Journal of Theology for Southern Africa 24(3), 3-11.

Du Toit, B., 2000, God? Geloof in 'n postmoderne tyd, CLF-Uitgewers, Bloemfontein.

Du Toit, P.R. (Flip), Hofmeyr, J.W. (Hoffie), Strauss, P.J. (Piet) \& Van der Merwe, J.M (Johan), 2002, Moeisame pad na vernuwing: Die NG Kerk se pad van isolasie en die soeke na 'n nuwe relevansie 1974-2002, Barnabas, Bloemfontein.

Elliott, M. (ed.), 2009, 1989: The year that definced today's world, TIME Books, New York, NY.

Erasmus, A.S. (Fanus), 2009, Prof. Johannes du Plessis 1868-1935. Baanbreker, verbreker van die Gereformeerde geloof? Universiteit van die Vrystaat, Bloemfontein.

Esterhuyse, W.P. (Willie), 1979, Afskeid van apartheid: Opstelle oor rassediskriminasie, Tafelberg, Kaapstad.

Esterhuyse, W.P. (Willie), 2012, Eindstryd: Geheime gesprekke en die einde van apartheid, Tafelberg, Kaapstad.

Frankel, P., 2001, An ordinary atrocity: Sharpeville and its massacre, Witwatersrand University Press, Johannesburg.

Gaum, F.M. (Fritz), 1997, Die verhaal van die Ned Geref Kerk se reis met apartheid 1960-1994, Hugenote-Uitgewers, Wellington.

Groenewald, E.P. (Evert), 1947, 'Apartheid en voogdyskap in die lig van die Heilige Skrif', in G. Cronjé \& W. Nicol (eds.), Regverdige Rasse-Apartheid, pp. 41-67, CSV Stellenbosch.

Heyns, J.A., 1973a, 'Die Skrifbeskouing in strukturele perspektief', in P.A. Verhoef, D.W. De Villiers \& J.L. De Villiers (eds.), Sol lustitiae: Erebundel opgedra aan proff. B.B. Keet, J.C.G Kotzé, J.J. Müller, W.J. van der Merwe, T.N. Hanekom en F.J.M. Potgieter pp. 65-77, N.G. Kerk-Uitgewers, Kaapstad.

Heyns, J.A., 1973b, Brug tussen God en mens: Oor die Bybel, N.G. Kerkboekhandel, Pretoria.

Hofmeyr, J.W. (Hoffie), 1986, 'Johannes du Plessis in kerkhistoriese perspektief: Ketter of profeet?' Theologia Evangelica (SA) 19(1), 4-14.

Hugo, P., 1998, 'The politics of "untruth": Afrikaner academics for apartheid', Politikon 25(1), 31-55. https://doi.org/10.1080/02589349808705052

Jablonski, N.G., 2012, Living color: The biological and social meaning of skin color, University of California Press, Berkeley, CA. 
Johanson, B., 1975, 'Race, mission and ecumenism: Reflections on the Landman report', Journal of Theology for Southern Africa 10(1), 51-61.

Jonker, L., Conradie, E. \& Botha, J., 2020, Die Bybel in Fokus: Hoe om gelowig én denkend te lees, Lux Verbi, Kaapstad.

Jonker, W.D. (Willie), 1975, Die Bybel en Gods wil vir ons lewe, N.G. Kerk-Uitgewers, Kaapstad.

Jonker, W.D. (Willie), 1998, Selfs die kerk kan verander, Tafelberg, Kaapstad.

Keet, B.B. (Bennie), 1949a, 'Die Heilige Skrif en apartheid', Die Kerkbode (30 November 1949), 1004-1005.

Keet, B.B. (Bennie), 1949b, 'Die Heilige Skrif en apartheid', Die Kerkbode (07 December 1949), 1046-1048.

Keet, B.B. (Bennie), 1949c, 'Die Heilige Skrif en apartheid', Die Kerkbode (14 December 1949), 1086-1087.

Keet, B.B. (Bennie), 1949d, 'Die Heilige Skrif en apartheid', Die Kerkbode (21 December 1949), 1137-1138.

Keet, B.B. (Bennie), 1956, Whither South Africa? University Publishers, Stellenbosch.

Kennedy, P., 2006, A modern introduction to theology: New questions for old beliefs, I.B. Tauris, London.

Kinghorn, J., 1986a, 'Vormende faktore', in J. Kinghorn (ed.), Die NG Kerk en Apartheid, vol. 1986, pp. 47-69, Macmillan, Johannesburg.

Kinghorn, J., 1986b, 'Die groei van 'n teologie - van sendingbeleid to verskeidenheidsteologie', in J. Kinghorn (ed.), Die NG Kerk en Apartheid, vol. 1986, pp. 86-143, Macmillan, Johannesburg.

Kinghorn, J. 1986c, "n Evaluasie van Apartheidsteologie', in J. Kinghorn (ed.), Die NG Kerk en Apartheid, vol. 1986, pp. 167-193, Macmillan, Johannesburg.

Kleynhans, E.P.J., 1983, Die vrou in die amp in die Nederduitse Gereformeerde Kerk, Universiteit van die Oranje Vrystaat, Bloemfontein.

Krentz, E., 1975, The historical-critial method, Fortress, Philadelphia, PA.

Langer, D., 2007, Knegte van die Allerhoogste, teen die héle wêreld vry: Koot Vorster - segsman of profeet? Griffel Media, Pretoria.

Le Roux, J.H. (Jurie), 1986, 'Johannes du Plessis as Bybelwetenskaplike', Theologia Evangelica (SA) 19(1), 15-35.

Loader, J.A., 1979, 'The use of the Bible in conventional South African theology', in W.S. Vorster (ed.), Scripture and the use of scripture, pp. 1-25, University of South Africa, Pretoria.

Lombaard, C.J.S., 2001, 'The Bible in the apartheid debate', in J.W. Hofmeyr, C.J.S Lombaard \& P.J. Maritz (eds.), 1948 plus fifty years: Theology, apartheid and church (past present and future), pp. 69-87, University of Pretoria Press, Pretoria.

Loubser, J.A. (Bobby), 1987, The Apartheid Bible: A critical review of racial theology in South Africa, Maskew Miller Longman, Cape Town.

Lubbe, J., 2002, Kleur verskil: 'n Perspektief op die NG Kerk in 1948 en apartheid as kerklike beleid, Barnabas, Bloemfontein.

Lückhoff, A.H., 1978, Cottesloe, Tafelberg, Kaapstad.

Marais, B.J., 1950, 'Die Skrif en rasseapartheid', Gereformeerde Vaandel 18(1), 14-25.

Marais, B.J., 1952, Colour: The unsolved problem of the West, HB Timmins, Cape Town.

Matisonn, J., 2015, God, spies and lies: Finding South Africa's future through its past Missing Ink, Vlaeberg.

Meiring, P.G.J. \& Lederle, H.I. (eds.), 1979, Die eenheid van die kerk, Tafelberg, Kaapstad.

Morris, M., 2012, Apartheid: An illustrated history, Jonathan Ball, Jeppestown.

Murray, B.K. \& Stadler, A.W., 1991, 'Van die Pakt tot die begin van apartheid, 1924-1948', in T. Cameron \& S.B. Spies (eds.), Nuwe Geskiedenis van Suid-Afrika: Hersiene uitgawe, pp. 249-270, Human \& Rousseau, Kaapstad.

Nel, A., 2003, Op soek na God ... buite die kerk? Wen weer ontnugterde gelowiges se vertroue, LuxVerbi.BM, Wellington.

Noll, M.A., 1991, Between faith and criticism: Evangelicals, scholarship and the Bible, Apollos, Leicester.

Olivier, A., 2009, 'Die jare van die leerstryd: 1910-1935', in P. Coertzen (ed.), Teologie Stellenbosch 150+: Die verhaal van teologiese opleiding op Stellenbosch - die mense en die geboue, pp. 15-21, Bybel-Media, Wellington.

Oosthuizen, J., 2016, Die NG Kerk se U-draai oor die Rubicon, LitNet Seminare en essays, viewed 09 May 2020, from https://www.litnet.co.za/die-ng-kerk-se-udraai-oor-die-rubicon/.

Pelzer, A.N., 1979, Die Afrikaner-Broederbond: Eerste 50 Jaar, Tafelberg, Kaapstad.

Perry, A., 2009, 'Setting a tone for history', in M. Elliott (ed.), 1989: The year that defined today's world, pp. 54-55, TIME Books, New York, NY.

Pistorius, P.V. (Villiers), 1950, 'Ons apartheidsbeleid en die Skrif', Gereformeerde Vaandel 18(1), 26-33.

Pistorius, P.V. (Villiers), 1957, No further trek, can, Johannesburg.

Potgieter, F.J.M., 1956, Veelvormige ontwikkeling-die wil van God, SACUM, Bloemfontein.

Potgieter, F.J.M., 1961. 'Is die apartheidsbeleid moreel te regverdig?' in G.B.A. Gerdener (ed.), Grense - ' $n$ simposium oor rasse en ander verhoudinge, pp. 1-8, Universiteits-uitgewers, Stellenbosch.

Potgieter, F.J.M., 1978, 'Eenheid en veelvormigheid prinsipieel verantwoord', in J.D. Vorster (ed.), Veelvormigheid en Eenheid, pp. 9-36, NG Kerk-Uitgewers, Kaapstad.
Potgieter, P.C., 1990, Skrif, dogma en verkondiging, Lux Verbi, Kaapstad.

RVN, 1975, Ras, Volk en Nasie en Volkereverhoudinge in die lig van die Skrif, NG KerkUitgewers, Kaapstad.

Sæbø, M., 1995, 'Some problems of writing a research history of Old Testament studies in the latter part of the nineteenth century with special regard to the life and work of William Robertson Smith', in W. Johnstone (ed.), William Robertson Smith: Essays in reassessment, pp. 243-251, Sheffield Academic Press, Sheffield.

Salemink, T., 1997, De Afrikaanse Mythe, Kok, Kampen.

Salemink, T. \& Van Dijk, B., 1989, Apartheid en kerkelijk verzet: In de schaduw van Nazi-Duitland, De Horstink, Leuven.

Shriver, G.H. (ed.), 1997, Dictionary of heresy trials in American Christianity, Greenwood Press, Westport, CT.

Smit, D.J. (Dirkie), 1987, Hoe verstaan ons wat ons lees? 'n Dink- en werkboek oor die hermeneutiek vir predikers en studente, NG Kerk-Uitgewers, Kaapstad.

Smit, D.J. (Dirkie), 2006, Neem, lees! Hoe ons die Bybel hoor en verstaan, LuxVerbi.BM, Wellington.

Smith, N., 2009, Die Afrikaner Broederbond: Belewinge van die binnekant, Lapa, Pretoria.

Snyman, G.F. (Gerrie), 2015, 'Totius: die ironie van vergewe en vergeet', LitNet Akademies 12(2), 211-235, viewed 01 May 2020, from https://www.litnet.co.za/ totius-die-ironie-van-vergewe-en-vergeet/.

Snyman, S.D. (Fanie), 1998, 'Gedagtes oor die funksionering van die Skrifgesag in die Nederduitse Gereformeerde Kerk', in F. Snyman (red.), Is die NG Kerk nog die NG Nederduitse Gereformeerde Kerk', in F. Snyman (red.), Is die NG Kerk nog die NG
Kerk: Antwoorde op die identiteitskrisis in die kerk, pp. 12-19, HugenoteKerk: Antwoorde op
Uitgewers, Wellington.

Spangenberg, I.J.J., 1993, 'Galileo Galilei en die boek Prediker: 'n Les uit die kerkgeskiedenis', Theologia Evangelica 26(2), 121-131.

Spangenberg, I.J.J. (Sakkie), 1994, 'Paradigmaveranderinge in die Bybelwetenskappe: n Bydrae tot die gesprek tussen die Bybelwetenskap en Sistematiese Teologie', Religion \& Theology 1(2), 144-184. https://doi.org/10.1163/157430194X00141

Spangenberg, I.J.J. (Sakkie), 1998, 'Op pad na 2000 - oftewel, oor al die dinge wat gebeur het', Old Testament Essays 11(3), 534-566.

Spangenberg, Izak J.J. (Sakkie), 2002a, Perspectives on the Bible: God's Word in ordinary language, Protea Book House, Pretoria.

Spangenberg, Izak J.J. (Sakkie), 2002b, 'Hoe dink vandag se mense oor die Bybel?', Verbum et Ecclesia 23(1), 183-195. https://doi.org/10.4102/ve.v23i1.1218

Sparks, A., 1994, Tomorrow is another country: The inside story of South Africa's negotiated revolution, Struik Book Distributors, Sandton.

Strauss, P.J., 2015, Gereformeerdes onder die Suiderkruis 1652-2011: Die verhaal van vier Afrikaanse kerke, Sun Media, Bloemfontein.

Van der Watt, P.B. (Flip), 1987, 'Die Ned. Geref. Kerk en die Rassevraagstuk', in P.B. van der Watt (ed.), Die Nederduitse Gereformeerde Kerk 1905-1975, pp. 75-118, N.G. Kerkboekhandel, Pretoria.

Van Heerden, C.I., 1978, 'Die oorkoepelende Sinode beoordeel vanuit die sendingkundige beginsel van selfstandigwording van kerke', in J.D. Vorster (ed.), Veelvormigheid en Eenheid, pp. 47-63, NG Kerk-Uitgewers, Kaapstad.

Van Heerden, S.W. (Willie), 1988, 'Die interpretasie van die boek Jona in die Nederduitse Gereformeerde Kerk: 'n Hermeneutiese Studie', Ongepubliseerde DTh-tesis, Universiteit van Suid-Afrika, Pretoria.

Van Rooyen, E.E., 1923, “'Het teken van Jona”: Allegorie of historie?' Het Zoeklicht $1(2), 245-249$

Van Wyk, J.A., 1976, 'Latente motiewe in die verklaring van die NG Kerk oor:Ras, volk en nasie en volkereverhoudinge in die lig van die Skrif', Nederduits Gereformeerde Teologiese Tydskrif 17(2), 98-109.

Van Zyl, H.C., 2001, 'Is die Bybel nog God se Woord?', in P. Meiring (red.), So glo ons: Gelowig nagedink oor God, die Bybel en ons leefwêreld, pp. 72-87, Christelike Uitgewersmaatskappy, Vereeniging.

Venter, E.A. (Rassie), 1950, 'Die Heilige Skrif en die apartheidsvraagstuk', Gereformeerde Vaandel 18(1), 5-13.

Vorster, J.D. (Koot), (ed.), 1978a, Veelvormigheid en Eenheid, N.G. Kerk-Uitgewers, Kaapstad.

Vorster, J.D. (Koot), 1978b, 'Meervormigheid in die eenheid', in J.D. Vorster (ed.), Veelvormigheid en Eenheid, pp. 78-86, N.G. Kerk-Uitgewers, Kaapstad.

Vorster, W.S., 1977, 'n Ou Boek in 'n nuwe wêreld - gedagtes rondom die interpretasie van die Nuwe Testament, Unisa, Pretoria.

Vorster, W.S., 1983, 'The Bible and apartheid 1', in J.W. De Gruchy \& C. Villa-Vicencio (eds.), Apartheid is a heresy, pp. 94-111, David Philip, Cape Town.

Vorster, W.S., 1984, 'The use of Scripture and the NG Kerk: A shift of paradigm or of values?' in J.W. Hofmeyr \& W.S. Vorster (eds.), New faces of Africa: Essays in values?'
honour of Ben (Barend Jacobus) Marais, pp. 204-219, Unisa, Pretoria.

Vorster, W.S., 1988, 'Oor lees, lesers en Johannes 4', in P.G.R. De Villiers (ed.), Hoe lees 'n mens die Bybel? pp. 1-29, Unisa, Pretoria.

Vosloo, R.R., 2015, 'The Bible and the justification of apartheid in Reformed circles in the 1940's in South Africa: Some historical, hermeneutical and theological remarks', Stellenbosch Theological Journal 1(2), 195-215. https://doi org/10.17570/stj.2015.v1n2.a09

Welsh, D., 2009, The rise and fall of Apartheid, Jonathan Ball, Jeppestown.

Wilkins, I. \& Strydom, H., 2012, The Super-Afrikaners: Inside the Afrikaner-Broederbond (Introduction to the new edition by Max du Preez), Jonathan Ball, Johannesburg. 